\title{
Thermo-economic Analysis of a Small Scale Retrofit Municipal Solid Waste Fueled Power Plant
}

\author{
Barinyima Nkoi, Confidence Koate, and Howells Idaerefagha Hart
}

\begin{abstract}
This paper evaluates the thermo-economics of a small scale retrofit municipal solid waste (MSW)-fuelled power plant proposed to be sited in Port Harcourt, Rivers State, Nigeria. The design parameters for the combustor which utilizes mass combustion in stoker crate furnace is operated at

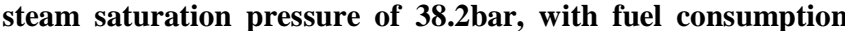
rate of $41.3 t o n n e / h r(11.88 \mathrm{~kg} / \mathrm{s})$ and was selected for the amount of MSW generated in Port Harcourt metropolis. The data used in assessing the availability of the fuel (MSW) were obtained from waste dumpsites controlled by Rivers State Waste Management Agency (RIWAMA). MATLAB Software modelling was used for the thermodynamic analysis to appropriately retrofit a steam turbine power cycle to the selected combustor and the result shows that the optimal performance of the proposed MSW plant gives a net power output of 5.23MW. The result further shows that heat energy in the steam entering the turbine is equivalent to $0.71 \mathrm{MWh}$ per tonne of waste. Therefore, at $17.3 \%$ thermal efficiency of the proposed MSW plant, 0.13 MWh of electricity will be produced per tonne of waste combusted. However, it is estimated that the plant may consume $15 \%$ of the electricity, which implies that $0.11 \mathrm{MWh} /$ tonne will be exported to the grid. Thus, as the plant is expected to process 340770.3tonnes/yr of MSW, the net electricity output of the proposed plant is estimated at 37.48GWh per year. The economic evaluations have shown that the Net present worth of the plant is $\$ 6395107.07$ with a payback period of 7 years for a 20 years life cycle. This work thus indicates huge potentials in generating electrical power and wealth from MSW in Port Harcourt and environs with the use of cheap and readily available fuel from municipal solid waste. It also reveals a viable and economical means of waste management in the city.
\end{abstract}

Index Terms-Municipal-Waste; Net-Present-Value; SteamFlow; Thermal-Efficiency; Waste-to-Energy.

\section{INTRODUCTION}

The production of municipal solid waste is growing at an ever-increasing rate and its accumulation is becoming a major problem. Consequently, more sustainable and acceptable waste management scheme is vital for every society. Nowadays, due to environmental, financial and social requirements, a more rational waste management is considered necessary. The willingness to minimize the accumulated waste along with the increased energy demand

Published on March 4, 2018.

B. Nkoi is with the Mechanical Engineering Department, Rivers State University, Port Harcourt, Nigeria (e-mail: nkoi.barinyima@ust.edu.ng).

C. Koate is a graduate student with the Mechanical Engineering Department, Rivers State University, Port Harcourt, Nigeria (e-mail: koateconfidence@yahoo.co.uk).

H. I. Hart is with the Mechanical Engineering Department, Rivers State University, Port Harcourt, Nigeria (e-mail: harthi78@yahoo.com; harthi78@gmail.com). has led to the development of the third-generation waste management systems. Such systems are the waste-to-energy (WTE) facilities which are considered friendly for both the environment and the society [1].

According to the work of [2] about 2.26MW of electrical energy could be generated daily from wastes per city in Nigeria. This is quite significant in the quest for alternative/complimentary energy source in Nigeria. To minimize waste management difficulties, the use of fuels like MSW is necessary. This may also provide another means of guaranteeing a sustainable energy supply [3]. The $\mathrm{CO}_{2}$ impact of $\mathrm{MSW}$ is close to that of biomass because MSW as a renewable energy source consists much of plantbased materials. MSW management can be enhanced by employing waste-to-energy (WTE) facilities. Reduction in greenhouse gas emissions can be achieved by encouraging biomass-based energy generation technology which would minimize open dumping of waste [4].

Efforts have been made by researchers to develop techniques to manage municipal solid waste in Nigeria and other developing countries with a view to reducing health hazards associated with poor management of solid wastes. One of the ways to manage MSW is its conversion to energy in the form of heat and electricity [5].

It has been found by [6] that municipal solid waste (MSW) generated in Port Harcourt are in very large quantities, but are mainly littered all over the city. Besides, they observed that refuse are mostly buried underground while some are recklessly burnt openly which constitute environmental hazards. Their empirical analysis showed that waste gathered from various dumpsites and receptacles in the city of Port Harcourt consisted of $66.6 \%$ volatile solids, $13.5 \%$ fixed solids, $19.1 \%$ liquid and $0.8 \%$ other compositions. Average biodegradability fraction was found to be 0.807 , with a carbon-to-nitrogen ratio of $27: 1$, and the energy content of the solid waste was calculated as 7.25 $\mathrm{MJ} / \mathrm{kg}$. They suggested that other options of refuse disposal could be used to reduce adverse impact on the environment.

Waste incineration is a process carried out with surplus of air and releases energy, producing solid residues as well as flue gas that is emitted into the atmosphere [7]. As a result of emission and safety concerns, there is a certain temperature range that is demanded for this type of process. In the case of mixed waste, a furnace temperature of $1050^{\circ} \mathrm{C}$ is required. A generic description of an incineration process shows that waste is first deposited and processed on a moving grate in order to achieve correct combustion. Before undergoing the combustion phase, the incoming waste could be exposed to pre-treatment, depending on its quality, composition and the selected incineration system [8]. 
It has been opined that high efficient electrical power generation system could be developed of WTE facilities by employing more advanced, high corrosion and stress resistant steels for boiler materials or coat boiler tubes with corrosion-resistant plating [9]. It was suggested that an alternative way could be to modify the entire WTE process. Many researchers are currently investigating this alternative way. Some WTE technologies have gained little success and therefore more researches and development are still required to be done in order to obtain a more reliable and highly efficient technology.

Different technologies have been deployed to obtain energy from MSW around the globe depending on the conditions of the waste in different regions. Nigeria as a developing nation is faced with power generation issues, particularly generation from non - conventional sources like renewable municipal solid waste. This research work thus presents a method of generation of electric power from MSW generated and collected in Port Harcourt using combustion pathway, retrofit technology. The paper further investigates the viability of using such technology. The main aim of this paper, therefore, is to conduct thermo-economic analysis of a proposed small scale retrofit municipal solid waste fueled power plant in Port Harcourt, Nigeria, as a way of harnessing the energy in municipal solid waste (MSW) for electricity generation in Port Harcourt. This would serve as an option to supplement power generation from conventional sources.

In doing so, the conditions of renewable municipal solid waste (MSW) generated in Port Harcourt were investigated; the minimum quantity of electrical power that can be generated from renewable MSW on daily basis was properly evaluated using appropriate thermodynamic and mathematical tools; and the economic viability of generation of electric power from MSW disposed and collected in Port Harcourt was technically evaluated.

\section{MEthodS}

\section{A. Description of the Proposed MSW-fuelled Steam Power Plant}

The power plant is designed to generate electric energy through direct combustion of Municipal Solid Waste. The plant (schematic diagram shown in Fig. 1) consists of the Combustor that is physically separated from the Boiler, Boiler with natural circulation of liquid water and steam in the Economizer, Evaporator and Superheater respectively, Steam Turbine, a single stage unit, Condenser, and Feed Pump.

The flue gas with enough heat energy exiting the combustion chamber is channelled to the boiler to produce high pressure steam by heating saturated water flowing into it from the pump. The flue gas during the process loses heat to the boiler and it goes through a cleaning system before it is being released to the atmosphere via the stack.

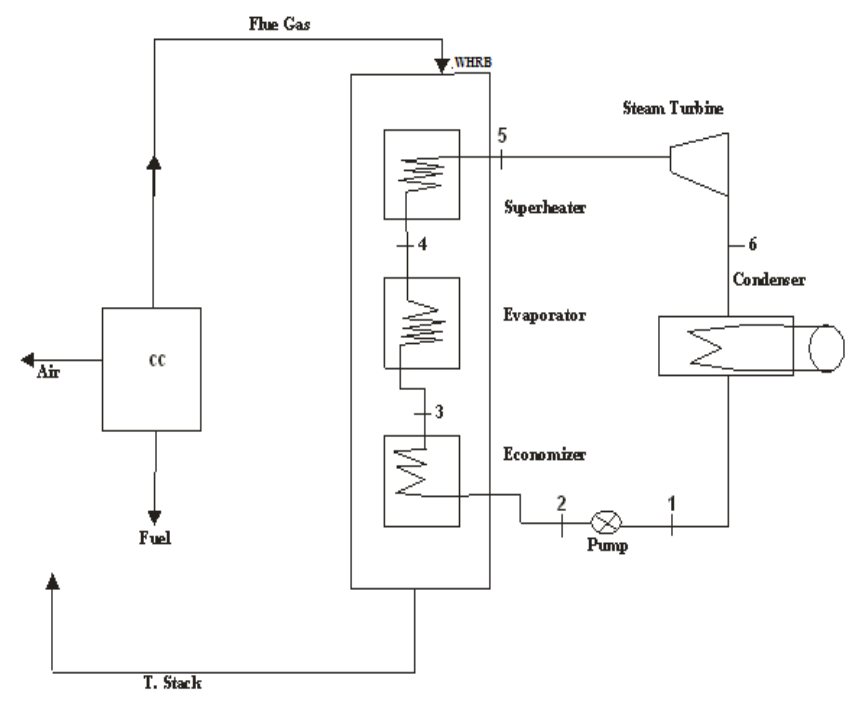

Fig. 1. Schematic Diagram of the Proposed Municipal Solid Waste-Fueled Power Plant

The steam power cycle principle is used for the thermodynamic analysis of the power plant. High pressure superheated steam produced in the boiler, at state 5 enters the single stage steam turbine where it is expanded to low pressure steam at state 6 thereby producing shaft power. The low-pressure steam is condensed in the condenser to saturated liquid water at state 1 . The resulting saturated liquid water is returned to the boiler by the feed pump and the cyclic process repeats. The steam turbine power cycle on a T-S diagram is as shown in Fig. 2.

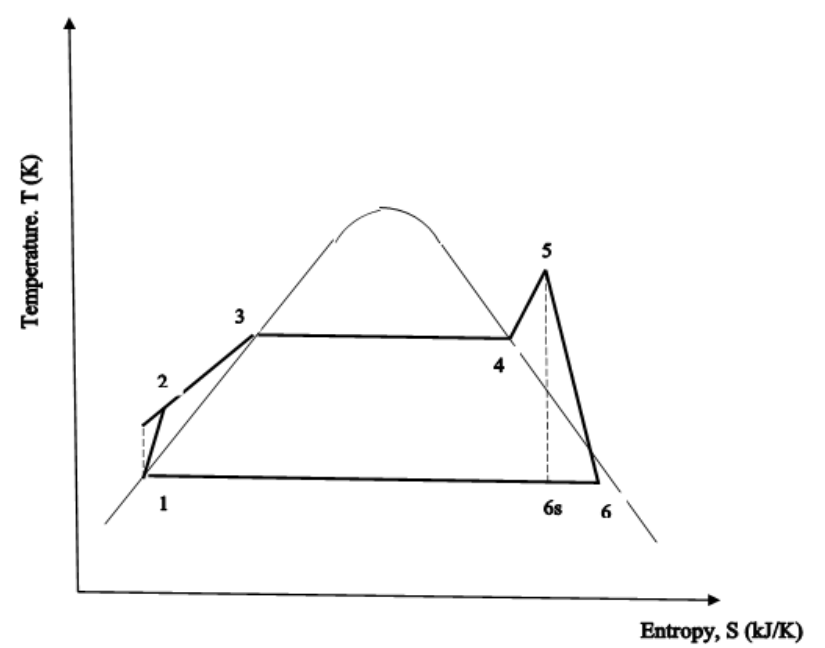

Fig. 2. T-S diagram of the steam turbine power cycle to be retrofitted

\section{B. Resources (Fuel) Availability Assessment and Thermo- Economic Models}

To ascertain the availability of the fuel, the mass flow of MSW is estimated for three dumpsites operated by the wastes management agency. The physical and chemical compositions of the MSW were also investigated to determine its suitability for energy conversion.

In the combustion chamber, MSW and air are burnt completely to produce high temperature flue gas that is used to heat the fluid flowing through the boiler. 


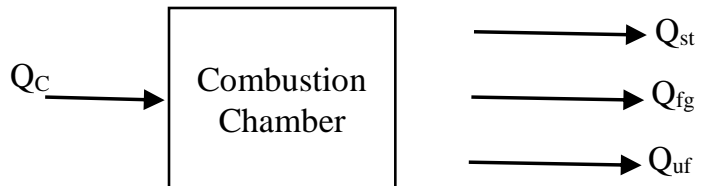

Fig. 3. Heat balance in the combustion chamber

Heat balance in the combustion chamber, Fig. 3 taken as a control volume is given by [4] as in (1)

$$
Q_{C}=Q_{s t}+Q_{f g}+Q_{u f}
$$

Where $\mathrm{Q}_{\mathrm{c}}$ is the heat liberated in the combustion chamber, $\mathrm{Q}_{\mathrm{st}}$ is the heat gained by steam in the boiler, $\mathrm{Q}_{\mathrm{fg}}$ is the heat loss by flue gas at stack exhaust and $\mathrm{Q}_{\mathrm{uf}}$ is the heat lost due to unburnt fuel.

$$
Q_{c}=\dot{m}_{f} C V_{f}
$$

where $\dot{m}_{f}$ is the mass flow of fuel (MSW) and $C V_{f}$ is the calorific value of the fuel.

$$
Q_{s t}=\dot{m}_{f g} C_{P f g}\left(T_{c}-T_{s}\right)
$$

where $\dot{m}_{f g}$ is the mass flow of the flue gas, $C_{P f g}$ is the specific heat capacity of the flue gas, $T_{C}$ is the combustion chamber temperature and $T_{s}$ is the stack temperature.

$$
\begin{gathered}
m_{f g}=m_{f}+m_{a} \\
C_{P f g}(T)=0.991615-\left[\frac{6.99703 T}{10^{5}}\right]+\left[\frac{2.7129 T^{2}}{10^{7}}\right]-\left[\frac{1.22442 T^{3}}{10^{10}}\right](5) \\
Q_{u f}=\dot{m}_{u f} C V_{f}
\end{gathered}
$$

where $m_{u f}$ is mass of unburnt fuel.

Applying the heat balance equations of the combustion chamber in conjunction with the schematic diagram of the steam cycle of the power plant (Fig. 1) gives:

$$
Q_{s t}=\dot{m}_{s}\left(h_{5}-h_{2 s}\right)=\dot{m}_{f g} C_{P f g}\left(T_{c}-T_{s}\right)
$$

$$
\begin{aligned}
& \text { and } \\
& \dot{m_{s}}=\dot{m}_{f g} C_{P f g}\left(\frac{T_{C}-T_{s}}{h_{5}-h_{2 s}}\right)
\end{aligned}
$$

Where $\mathrm{m}_{\mathrm{s}}$ is the mass flow rate of the steam produced in the boiler, $h_{5}$ and $h_{2 s}$ are the specific enthalpies of the steam at the boiler exit and inlet respectively.

The heat added in each component of the heat recovery boiler are given by [9] as follows:

The Super heater:

$$
Q_{S H}=\dot{m}_{s}\left(h_{5}-h_{4}\right)
$$

The Evaporator:

$$
Q_{E V}=\dot{m}_{s}\left(h_{4}-h_{3}\right)
$$

The Economizer:

$$
Q_{E C}=\dot{m}_{s}\left(h_{3}-h_{2 s}\right)
$$

Total heat added in the Boiler is given by the relation,

$$
Q_{B}=\mathrm{Q}_{\mathrm{EC}}+\mathrm{Q}_{\mathrm{EV}}+\mathrm{Q}_{\mathrm{SH}}
$$

The boiler efficiency is calculated using the relation,

$$
\eta_{B}=\frac{\text { Heat } \sup \text { plied }}{\text { Fuelenergy }}=\frac{\dot{m}\left(h_{5}-h_{2 s}\right)}{\dot{m}_{f} C V_{f}} \times 100
$$

The actual power output of the steam turbine is determined using the isentropic efficiency as shown in (14).

$$
\eta_{\text {isen }}=\frac{P_{S T}(\text { actual })}{P_{S T}(\text { isentropic })}=\frac{\dot{m}_{s}\left(h_{5}-h_{6}\right)}{\dot{m}_{s}\left(h_{5}-h_{6 s}\right)}
$$

that is,

$$
P_{S T}(\text { actual })=\eta_{\text {isen }} \times \dot{m}_{s}\left(h_{5}-h_{6 s}\right)
$$

and

$$
h_{6}=h_{f 6}+x_{6} h_{f g 6}
$$

where $\mathrm{P}_{\mathrm{ST}}$ is the power developed at the steam turbine generator terminal, $\eta_{\text {isen }}$ is the isentropic efficiency of the steam turbine and $h_{6}$ is the specific enthalpy of steam at turbine exit $\mathrm{x}_{6}$ is the dryness fraction of the steam exiting the turbine. Considering an isentropic process, the heat rejected in the condenser is presented as:

$$
Q_{C D}=\dot{m}_{s}\left(h_{6 s}-h_{1}\right)
$$

The pump power input is given by the relation,

$$
P_{P}=\dot{m}_{s}\left(h_{2 s}-h_{1}\right)
$$

The net power output of the power plant is given by,

$$
P_{N E T}=P_{S T}-P_{P}
$$

The steam turbine cycle thermal efficiency is given by, 


$$
\eta_{S T}=\frac{P_{N E T}}{Q_{B}}
$$

The Net Present Value (NPV) is used to assess the future series of after-tax cash flow (ATCF) realised for the power generation and utilization. The NPV of the financial benefits is compared with the NPV of the investment to determine whether the investment has a positive return. Mathematically the NPV as expressed by [10] is given as stated in (21).

$$
N P V=-F_{o}+\sum_{t=1}^{N} \frac{F_{t}}{\left(1+d_{t}\right)^{t}}
$$

Where:

$d_{t}$ is the market discount rate during the period $t$ in years, and when it is considered constant $\mathrm{d}_{\mathrm{t}}=\mathrm{d}$

$\mathrm{N}$ is the period in time in years for which the plant is assumed to operate

$F_{t}$ is the net cash flow in years $t$

$F_{0}$ is the present worth of the investment (at time $t=0$ )

The internal rate of return (IRR) is the discounted rate that results in an NPV value of zero. This means that the IRR is the discount rate that makes the net present worth of the future cash flow equal the plant capital investment cost. It is evaluated using iteration techniques. That is,

$$
F_{0}=\sum_{t=1}^{N} \frac{F_{t}}{(1+I R R)^{t}}
$$

\section{Where}

IRR is the internal rate of return

$\mathrm{N}, \mathrm{F}_{\mathrm{t}}$, and $\mathrm{F}_{0}$ are as defined in (21).

The simple-payback-period (SPBP) is the length of time usually in years taken to recover the initial cost of investment of the MSW power plant based on the annual savings realised. That is,

$S P B P($ years $)=\frac{\text { Capital investment cost of MSW plant }}{\text { Annual saving from the Energy Generated by the plant }}$

Some unit cost elements and assumptions used in the economic analysis are shown in Table I including their

\begin{tabular}{|c|c|c|}
\hline Parameter & Values & $\begin{array}{l}\text { Referen } \\
\text { ces }\end{array}$ \\
\hline Boiler capital cost & $104.98(\$ / \mathrm{kW})$ & {$[11][10]$} \\
\hline $\begin{array}{l}\text { Boiler operation \& maintenance } \\
\text { cost }\end{array}$ & $0.0052(\$ / \mathrm{kWh})$ & [11] \\
\hline MSW plant capital cost $\leq 10 \mathrm{MW}$ & $1531(\$ / \mathrm{kW})$ & {$[12]$} \\
\hline $\begin{array}{l}\text { MSW plant operation \& } \\
\text { maintenance cost }\end{array}$ & $342.82(\$ / \mathrm{kWh})$ & [12] \\
\hline Cost of Energy (Nigeria) & $\begin{array}{l}30.23(\mathrm{~N} / \mathrm{kWh}) \\
(0.083 \$ / \mathrm{kWh})\end{array}$ & {$[13]$} \\
\hline Cost of MSW collection & $0.022(\$ /$ tonne/yr $)$ & [14] \\
\hline Plant Availability & $91 \%(8000 \mathrm{hrs})$ & {$[10]$} \\
\hline $\begin{array}{l}\text { Discount rate }(\mathrm{d}) \text {, Electricity tariffs } \\
\text { escalation rate, MSW collection } \\
\text { escalation rate, O\&M escalation } \\
\text { rate and Plant life cycle }(\mathrm{N})\end{array}$ & $\begin{array}{l}10 \%, 5 \%, 1 \%, 3 \% \\
\text { and 20years } \\
\text { respectively }\end{array}$ & {$[10][15]$} \\
\hline
\end{tabular}
source references.
TABLE I: COST CONSIDERATIONS AND ASSUMPTIONS

\section{RESUlTS AND DISCUSSION}

\section{A. MSW Power Plant Design and Performance Analysis}

The result shows that 41.3 tonne/hr is generated and there is a need to get a combustor that can burn the amount of waste indicated. The design data of the MSW combustor chosen for the retrofitting is shown in Table II. The data is used as the basis to carry out a retrofitting iteration calculation to know the actual capacity of the MSW boiler and the steam turbine plant needed for power generation. Eight iterations (cases) at different steam saturation pressure and stack temperature were evaluated and result shown in Table III.

TABLE II DESIGN DATA FOR MSW COMBUSTOR (ZG-45/3.82-T) [16]

\begin{tabular}{ll}
\hline Parameter & Values \\
\hline Capacity & 45 tonnes $/ \mathrm{hr}(12.5 \mathrm{~kg} / \mathrm{s})$ \\
Saturation Pressure & $38.2 \mathrm{bar}$ \\
Steam Temperature & $400^{\circ} \mathrm{C}$ \\
Feed Water Temperature & $105^{\circ} \mathrm{C}$ \\
Mass of Air required/ Kilogram of MSW & 283 tonne $/ \mathrm{hr}(78.7 \mathrm{~kg} / \mathrm{s})$ \\
Mass of flue gas & 314 tonne $/ \mathrm{hr}(87.1 \mathrm{~kg} / \mathrm{s})$ \\
Calorific Value of the MSW & $15632 \mathrm{~kJ} / \mathrm{kg}$ \\
\hline
\end{tabular}

\section{B. Retrofit Steam Turbine Power Plant Analysis}

. To utilize the energy from the flue gas in the chosen combustor to burn 41.3 tonnes/hr of MSW, a steam turbine retrofitting design is required to actually know the capacity. To achieve this, eight different iterations were carried at chosen saturation pressure and stack temperature as shown

\begin{tabular}{|c|c|c|c|c|c|c|c|c|c|}
\hline Cases & $\begin{array}{l}\mathrm{P}_{5} \\
{[\text { bar] }}\end{array}$ & $\mathrm{T}_{\mathrm{s}}$ & {$\left[{ }^{\circ} \mathrm{C}\right]$} & $\begin{array}{l}\mathrm{m}_{\mathrm{s}} \\
{[\mathrm{kg} / \mathrm{s}]}\end{array}$ & $\begin{array}{l}\mathrm{Q}_{\mathrm{B}} \\
{[\mathrm{MW}]}\end{array}$ & $\begin{array}{l}\mathrm{P}_{\mathrm{ST}} \\
{[\mathrm{MW}]}\end{array}$ & $\begin{array}{ll}\mathrm{W}_{\mathrm{P}} & {[\mathrm{MW}]}\end{array}$ & $\begin{array}{l}P_{\text {net }} \\
{[\mathrm{MW}]}\end{array}$ & $\begin{array}{l}\eta_{\text {MSWplant }} \\
{[\%]}\end{array}$ \\
\hline 1 & 20 & 170 & & 9.8482 & 30.1642 & 5.4752 & 2.0886 & 3.3866 & 11.2 \\
\hline 2 & 20 & 180 & & 9.8482 & 29.2502 & 5.4752 & 3.0027 & 2.4725 & 8.5 \\
\hline 3 & 30 & 170 & & 9.4917 & 30.1634 & 5.5245 & 0.8166 & 4.7079 & 15.6 \\
\hline 4 & 30 & 180 & & 9.4917 & 29.2503 & 5.5245 & 1.7306 & 3.3939 & 13.0 \\
\hline 5 & 35 & 170 & & 9.3463 & 30.1634 & 5.5215 & 0.2917 & 5.2308 & 17.3 \\
\hline 6 & 35 & 180 & & 9.3463 & 29.2502 & 5.5215 & 1.2047 & 4.3168 & 15.0 \\
\hline 7 & 40 & 170 & & 9.2143 & 30.1641 & 5.5239 & -1.7508 & 7.2747 & 24.0 \\
\hline 8 & 40 & 180 & & 9.2143 & 29.2501 & 5.5239 & 0.7240 & 4.999 & 16.4 \\
\hline
\end{tabular}
in Table III.

TABLE III: RESULT OF THE THERMODYNAMIC ANALYSIS OF THE RETROFITTED MSW-FUELLED POWER PLANT

The result from the analysis shows that the heat in the steam entering the turbine is equivalent to $0.71 \mathrm{MWh}$ per tonne of waste. At a steam temperature $400^{\circ} \mathrm{C}$ and pressure of $35 \mathrm{bar}$, the thermal efficiency of the plant is evaluated at
$17.3 \%$ as shown in case 5. Therefore $0.13 \mathrm{MWh}$ of electricity will be produced per tonne of waste combusted. However, it is estimated that the plant may consume $15 \%$ of the electricity, which implies that $0.11 \mathrm{MWh} /$ tonne will be 
exported to the grid. Therefore, if the plant is expected to process 340770.3tonnes/yr, the net electricity output of the proposed plant is estimated at $37.48 \mathrm{GWh}$.

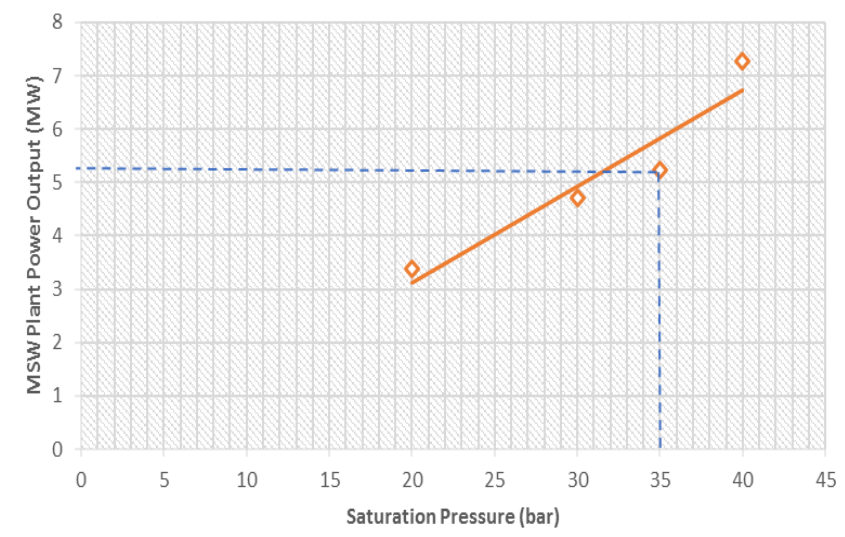

Fig. 4. Variation of MSW Plant Net Power Output with Saturation Pressure

From the analysis, the result show that for cases 1, 3 and 5 as the saturation pressure increase at constant stack temperature, the MSW net power generated increases. This trend is evident in the graph of Fig. 4. Similarly, for cases 2, 4 and 6 , the trend increases likewise. The result further shows that for every $1 \%$ increase in the saturation pressure, the MSW net power output increase by $0.37 \%$ at $170^{\circ} \mathrm{C}$ stack temperature, while for $1 \%$ increase in the saturation pressure at the stack temperature of $180^{\circ} \mathrm{C}$, the MSW plant net power output increases by $0.38 \%$. Although in case 7 , we have higher value but a constraint is observed because of the negative pump work, which created an impossible scenario. Therefore, the optimal design point based on the choice of the MSW combustor is case 5 as indicated with $5.23 \mathrm{MW}$ power output.

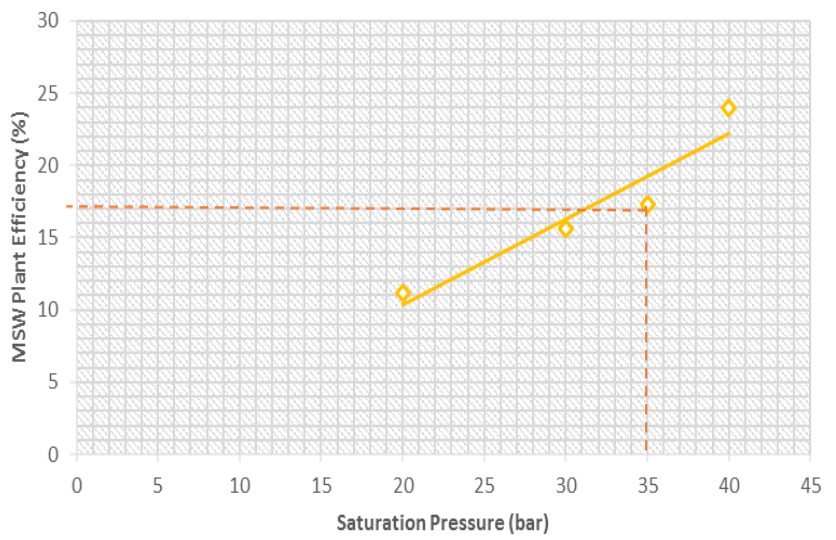

Fig. 5. Variation of MSW Plant Efficiency with Saturation Pressure

Fig. 5 revealed that for the stack temperatures of $170^{\circ} \mathrm{C}$ and $180^{\circ} \mathrm{C}$, the MSW plant thermal efficiency increases by $1.22 \%$ and $1.30 \%$ respectively for every $1 \%$ increase in the saturation pressure between cases 1-6.

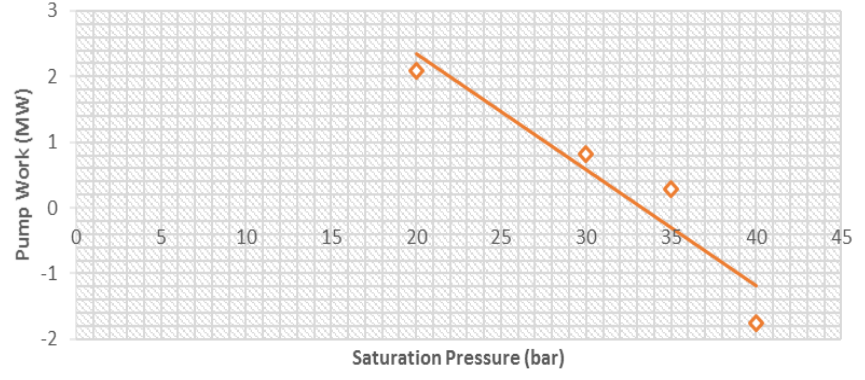

Fig. 6. Variation of MSW Plant Pump Work with Saturation Pressure

Fig. 6 show the design values of the pump required for the plant under various considerations. The result show that the pump drops consistently as the steam pressure increases at the two stack temperatures. For case 5, from the point of optimal design analysis, we have the minimum pump work.

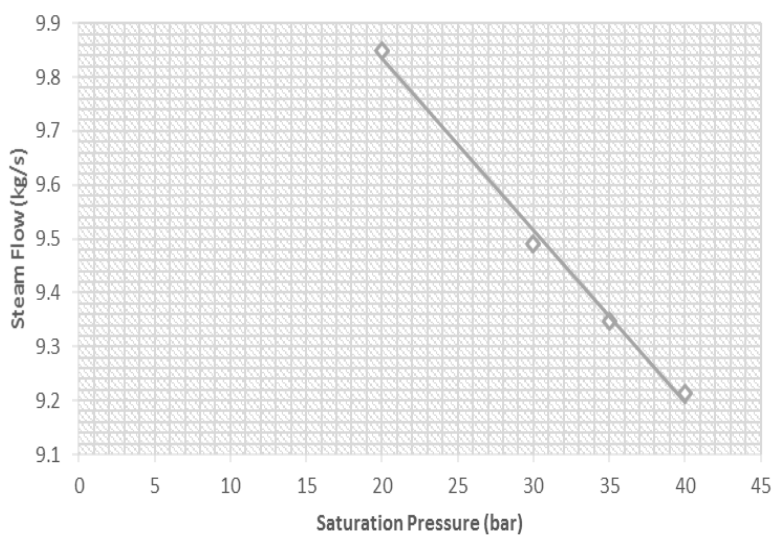

Fig. 7. Variation of Steam Flow with Saturation Pressure

Fig. 7 shows the trend of the steam generated with variation in the saturation pressure. It reveals that for every $1 \%$ increase in the saturation pressures the steam flow increases by $0.1 \%$ at $170^{\circ} \mathrm{C}$ and $180^{\circ} \mathrm{C}$ stack temperatures. This implies that the stack temperature effect on the steam flow is negligible.

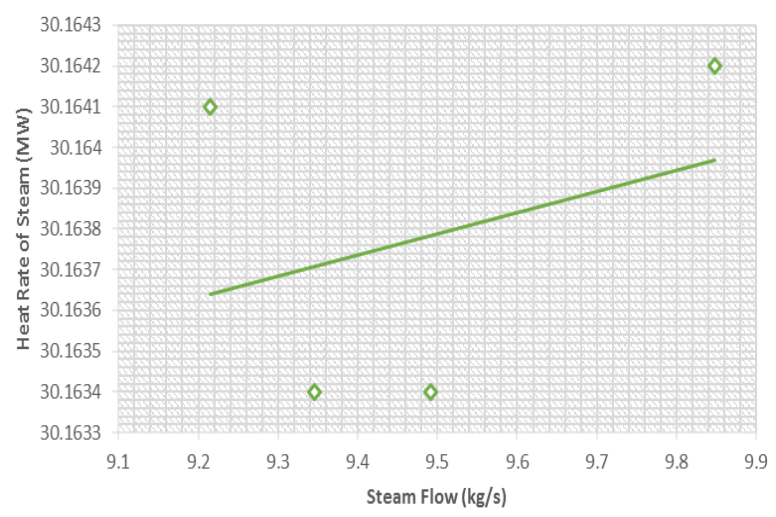

Fig. 8. Variation of Heat Rate of Steam Generated with Steam Flow

Fig. 8 shows that the increase in the steam flow increases the heat rate of the steam entering the turbine. This implies that there is a direct proportional relation. This also gives us a guide on the choice of boiler needed for steam generation of the prevailing tonne of MSW available. 


\section{Results of the Economic Analysis of the Retrofit MSW Plant}

The proposed plant at the preliminary design stage of
5.23MW was analysed using the highlighted economic tools to test its viability. The analysis was done using the various considerations as shown in Table IV

TABLE IV: PERFORMANCE ANALYSIS OF THE RETROFITTED MSW POWER PLANT

\begin{tabular}{|c|c|c|c|c|c|c|}
\hline $\begin{array}{l}\text { Month of } \\
\text { Operation }\end{array}$ & $\begin{array}{c}\text { Net Electrical Power } \\
\text { Generated (Avrg) (MW) }\end{array}$ & $\begin{array}{l}\text { Hour of Plant } \\
\text { Operation (hr) }\end{array}$ & $\begin{array}{c}\text { MSW Plant } \\
\text { Available Energy } \\
\text { (kWhe) }\end{array}$ & $\begin{array}{c}\text { MSW Plant } \\
\text { Energy Outages } \\
(\mathrm{kWh})\end{array}$ & $\begin{array}{l}\text { MSW Plant } \\
\text { Revenue } \\
\text { (\$/kWhe) }\end{array}$ & $\begin{array}{c}\text { Cost of Outages } \\
\$ / \mathrm{kwhe}\end{array}$ \\
\hline January & 4.45 & 663 & 2950350 & 517140 & 244879.05 & 42922.62 \\
\hline February & 4.45 & 678 & 3017100 & 528840 & 250419.30 & 43893.72 \\
\hline March & 4.45 & 690 & 3070500 & 538200 & 254851.50 & 44670.60 \\
\hline April & 4.45 & 700 & 3115000 & 546000 & 258545.00 & 45318.01 \\
\hline May & 4.45 & 586 & 2607700 & 457080 & 216439.11 & 37937.64 \\
\hline June & 4.45 & 698 & 3106100 & 544440 & 257806.32 & 45188.52 \\
\hline July & 4.45 & 680 & 3026000 & 530400 & 251158.01 & 44023.21 \\
\hline August & 4.45 & 695 & 3092750 & 542100 & 256698.25 & 44994.32 \\
\hline September & 4.45 & 583 & 2594350 & 454740 & 215331.05 & 37743.42 \\
\hline October & 4.45 & 667 & 2968150 & 520260 & 246356.45 & 43181.58 \\
\hline November & 4.45 & 680 & 3026000 & 530400 & 251158.10 & 44023.22 \\
\hline \multirow[t]{2}{*}{ December } & 4.45 & 680 & 3026000 & 530400 & 251158.01 & 44023.21 \\
\hline & & 8000 & 35600000 & 6240000 & 2954800.11 & 517920.02 \\
\hline
\end{tabular}

The cost of MSW collected as fuel $\left(\frac{\text { tonnes }}{y r}\right)=$ Waste generated (tonnes $) \times$ Percentage of waste collected $\times$ cost of waste collected $\left(\frac{\$}{\text { tonnes }}=\$ 0.022\left(\frac{\text { tonnes }}{y r}\right) \times 329480=\$ 7256.4\right.$

The simple payback period (SPBP) calculated is 6.1years (approximately 7years) given that the capital investment cost of WSM plant is $\$ 8,007,130.9$.

The result of the predicted performance analysis of the plant design is shown in Table IV. The analysis was based on the net electricity generated of $4.45 \mathrm{MW}$ which represent $14.9 \%$ deviation from design. This was to account for possible losses for the period of operation. Using the availability of $91 \%$, the operating hours were distributed according to the period under consideration.
The NPV technique was employed to predict the viability of the proposed 5.23MW plant for energy generation. That is,

$$
\begin{aligned}
& \text { Initial cash flow } F_{0}=(1 \times 5.23 M W) \\
& \quad \times \text { capital cost of MSW plant }\left(\frac{\$}{\mathrm{~kW}}\right) \\
& =(1 \times 5.23 \mathrm{MW}) \times 1531 \$ / \mathrm{kW}=\$ 8007130 \\
& \text { The annual plant operation \& maintenance cost } \\
& =\text { plant capacity }(\mathrm{kW}) \times 0 \& M \text { cost per } \mathrm{kW} \\
& =5230(\mathrm{~kW}) \times \frac{\$ 342.82}{\mathrm{kWyr}}=\$ 1792948.62
\end{aligned}
$$

\begin{tabular}{|c|c|c|c|c|c|}
\hline $\begin{array}{l}\text { End of } \\
\text { year }\end{array}$ & $\begin{array}{l}\text { MSW Plant O\&M Cost } \\
(3 \% \text { escalation rate) }(\$)\end{array}$ & $\begin{array}{l}\text { MSW Collection Cost } \\
\text { (3\% escalation) (\$) }\end{array}$ & $\begin{array}{l}\text { MSW Annual Electricity } \\
\text { Revenue (\$) (4\% escalation due } \\
\text { to tariff) }\end{array}$ & $\begin{array}{l}\text { MSW Plant Annual } \\
\text { net cash flow Ft (\$) }\end{array}$ & $\begin{array}{l}\text { Present value }(10 \% \\
\text { discount rate })(\$) \\
\mathrm{Ft} /(1+\mathrm{d})\end{array}$ \\
\hline 1 & 1792948.62 & 7256.48 & 2954800 & 1154594.9 & 1049631.727 \\
\hline 2 & 1846737.079 & 7329.0448 & 3072992 & 1218925.877 & 1007376.758 \\
\hline 3 & 1902139.191 & 7548.916144 & 3195911.68 & 1286223.573 & 967085.3932 \\
\hline 4 & 1959203.367 & 7775.383628 & 3323748.147 & 1356769.397 & 929294.1075 \\
\hline 5 & 2017979.468 & 8008.645137 & 3456698.073 & 1430709.96 & 888639.7269 \\
\hline 6 & 2078518.852 & 8248.904491 & 3594965.996 & 1508198.24 & 852089.401 \\
\hline 7 & 2140874.417 & 8496.371626 & 3738764.636 & 1589393.847 & 815073.7677 \\
\hline 8 & 2205100.65 & 8751.262775 & 3888315.221 & 1674463.309 & 782459.4901 \\
\hline 9 & 2271253.669 & 9013.800658 & 4043847.83 & 1763580.36 & 747279.8136 \\
\hline 10 & 2339391.279 & 9284.214678 & 4205601.743 & 1856926.249 & 716959.9418 \\
\hline 11 & 2409573.018 & 9562.741118 & 4373825.813 & 1954690.054 & 685856.1594 \\
\hline 12 & 2481860.208 & 9849.623352 & 4548778.846 & 2057069.014 & 655117.5204 \\
\hline 13 & 2556316.015 & 10145.11205 & 4730729.999 & 2164268.873 & 627324.311 \\
\hline 14 & 2633005.495 & 10449.46541 & 4919959.199 & 2276504.239 & 600660.7491 \\
\hline 15 & 2711995.66 & 10762.94938 & 5116757.567 & 2393998.958 & 572727.0235 \\
\hline 16 & 2793355.53 & 11085.83786 & 5321427.87 & 2516986.503 & 548363.0725 \\
\hline 17 & 2877156.195 & 11418.41299 & 5534284.985 & 2645710.376 & 522867.6633 \\
\hline 18 & 2963470.881 & 11760.96538 & 5755656.384 & 2780424.538 & 500076.3557 \\
\hline 19 & 3052375.008 & 12113.79434 & 5985882.64 & 2921393.838 & 477351.9342 \\
\hline \multirow[t]{2}{*}{20} & 3143946.258 & 12477.20817 & 6225317.945 & 3068894.479 & 456002.1514 \\
\hline & 48177200.86 & 191339.134 & 87988266.58 & 3961972658 & 14402237.07 \\
\hline
\end{tabular}

TABLE V: NPV ECONOMIC ANALYSIS OF THE RETROFITTED MSW PLANT VIABILITY

The result of the analysis as shown in Table $\mathrm{V}$, gave an estimated annual running cost of the MSW plant, the present value of the annual running cost of the plant and the present value of the first-year annual cash flow of the plant is $\$ 1,800,205.08, \quad \$ 1,049,631.73$ and $\$ 1,154,594.91$ respectively.
The result further shows that the initial cost of investment for the plant is $\$ 8,007,130$. The plant O\&M cost and the MSW collection cost for the first year of operation represent $23.4 \%$ and $0.09 \%$ respectively, with an annual cash flow of $\$ 1,154,594.91$. This represents about $14.4 \%$ of the initial cost of investment. The present values of the annual running cost at the end of the first year of power generation represent 
$13.1 \%$ of the cost of investment. The result further shows that for every $1 \%$ increase in the cost of the plant operation based on the escalation consideration, the cash flow increases by $1.4 \%$. This represents a positive trend for investment.

The net present value of the plant for the predicted operating period of twenty (20) years gave the worth of $\$ 6,395,107.07$, which represent $79.9 \%$ of the initial cost of investment in the MSW power plant. This is a positive trend which also proves that the waste-to-energy investment is viable. The payback period for the investment which is the ratio of the initial cash flow to the conventional annual running cost is about 7years for the 20years period of operation. This shows a good payback-period for the investment and it is an indication that the MSW plant is viable and has medium and long-term profit maximization.

\section{CONCLUSION}

The Thermo-economic analysis of municipal solid waste fueled power plant has been done with the operational conditions taken into account. The findings of this research shows that energy in form of electricity can be produced from municipal solid wastes using appropriate design parameters and conditions. With a feedstock (fuel) of 340770.3 tonne/yr $(11.88 \mathrm{~kg} / \mathrm{s})$ of $\mathrm{MSW}$ for plant running 8000 hours annually, about $9.3463 \mathrm{~kg} / \mathrm{s}$ of steam can be produced. This flow rate of steam at a turbine inlet temperature of $400^{\circ} \mathrm{C}$ and saturation pressure of $35 \mathrm{bar}$ can be used to drive a turbine to produce a net power of $5.2308 \mathrm{MW}$ of which about $2.64 \mathrm{MW}$ could be exported to the grid after auxiliary consumption of part of the generated power at the power station every hour. This result compares favorably with the results of other works in the literatures reviewed in this work.

The economic analysis carried out indicates that the payback period is about 7years for the plant of 20years life cycle. This signifies that the proposed power plant is viable. More so, with attractive interest rate and lower inflation rate, a better scenario could be achieved.

It should be noted that the production of municipal solid waste is constantly on the increase as a result of the rapid population growth, rural-urban migration, the everaccelerating urbanization and the continued improvement of standard of living of residence cities. Therefore, means such as utilization of MSW as a WTE technology should be implemented in order to provide avenue for economic disposal of waste as well as increasing power generation in cities such as Port Harcourt and its environs.

\section{ACKNOWLEDGMENT}

The authors would like to appreciate the contribution of Prof. O.M.I. Nwafor of the Department of Mechanical Engineering, Federal University of Technology, Owerri, for his corrective comments to improve the work of this paper.

\section{REFERENCES}

[1] V. Soulios, D. Kosmas, V. Metavitsiadis and G. Marnelos (2015), "Production of electricity from municipal solid waste in kos", Proceedings of the 14th International Conference on Environmental Science and Technology Rhodes, Greece, 3-5, September, 2015.
[2] A.A. Ujile and B.T. Lebele-Alawa, "Energy Conversion from Municipal Solid Waste in Nigeria", 2011. Available: www.researchgate.net/...ujile.

[3] S.O. Abah, and E.I. Ohimain, "Assessment of Dumpsite Rehabilitation Potential Using the Integrated Risk Based Approach: A case Study of Eneka, Nigeria", Journal of World Applied Science, 8,436-442, 2010

[4] C. Coskun, Z. Oktay, and N.A. Iten, "New Approach for Simplifying the Calculation of Flue Gas Specific Heat and Specific Exergy Value Depending on the Fuel Consumption", Energy Journal, 34,18981902, 2009.

[5] A. A. Ujile, (2008) "Technique of Municipal Waste Management in Port Harcourt, Rivers State, Nigeria", Proceedings of $23^{\text {rd }}$ International Conference on Solid Waste Technology and Management. Philadelphia, P.A., U.S.A. March-April, 2008. 473-481.

[6] S. O. T. Ogaji, S.D. Probert, A.H. Igoni and M.J. Ayotamuno, "Municipal solid-waste in Port Harcourt", Applied Energy, 84, 6, 2006.

[7] T. Hulgaard, and J. Vehlow, "Incineration: process and technology", Solid waste technology \& management, 2011.

[8] J.M. Ayotamuno, and E.A. Gobo, "Municipal Solid Waste Management in Port Harcourt, Nigeria: Obstacles and Prospects", Int J. Mgt. Environ. Qual, 15,389-398, 2004.

[9] V. Ganapathy, Steam Generators and Waste Heat Boilers for Process and Plant Engineers, CRC Press, Paperback, New York. 2015.

[10] B. Nkoi, P. Pilidis, and T. Nikolaidis, "Techno-economic Assessment of Large-Scale Aero-Derivative Industral Gas Turbine Combined Heat and Power". International Journal of Engineering and Technology,5, 225-240, 2015.

[11] National Renewable Energy Laboratory (NREL) Cost and Performance Data for Power Generation Technologies, Black and Veatch Corporation, 9-35, 2013.

[12] Energy Information Administration (EIA) USA, Updated Capital Cost Estimates for Utility Scale Electricity Generating Plants, 2013.Available: www.eig.gov

[13] Nigerian Electricity Regulatory Commission (NERC), Energy Tariff Report Schedule, 2017. Available: www.nercng.org

[14] World Bank, Urban Development Series-Knowledge Papers, 2010. Available: www.siteresources.worldbank.org

[15] DECC, Industrial Energy Prices Statistics, Energy Co-operation with developing Countries, $2013 . \quad$ Available: http://www.Europa.eu/scadplus/leg/en/lvb/r/2008.html

[16] Biomass Power Plant Boiler. Available: http://www.zzboiler.org/Straw-Biomass-Power-Plant-Boiler.html

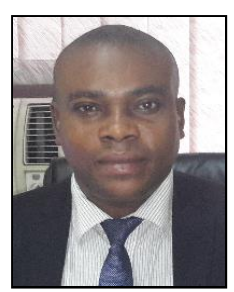

Barinyima Nkoi was born in Barayowa Dere in Gokana of Rivers State, Nigeria on 15th March, 1973. He obtained a Ph.D degree in Thermal power (Gas turbine engineering) from Cranfield University, Bedfordshire, United Kingdom, in 2015. He has Master of Technology (Thermo-fluid) and Bachelor of Technology degrees in Mechanical Engineering from Rivers State University, Port Harcourt, Nigeria in 2008 and 2000 respectively. He is the immediate past HEAD OF DEPARTMENT of Mechanical Engineering of Rivers State University, Port Harcourt, Nigeria where he started his teaching career as GRADUATE ASSISTANT in 2003 and rose to the rank of LECTURER till date. He has made the following paper publications among others:

B. Nkoi, K. Israel, and S. Adumene, "Performance analysis of an Energy System in the Tropical Rainforest: A Thermo-Economic Approach", Journal of Power and Energy Engineering, 6, 8-20, 2018. https://doi.org/10.4236/jpee.2018.61002;

B. Nkoi, and T.E. Isaiah, "Advanced Cycles Large-scale Aero-derivative gas turbine: Performance Comparison" Journal of Power and Energy $\begin{array}{llll}\text { Engineering, } & \text { vol.4 } & \text { no.5 } & 7-19,\end{array}$ http://dx.doi.org/10.4236/jpee.2016.45002.; and

B. Nkoi, and B.T. Lebele-Alawa, "Comparative Assessment of Combined-heat-and-power Performance of Small-scale Aero-derivative gas turbine cycles", Journal of Power and Energy Engineering, 3, 20 - 32,2015. http://dx.doi.org/10.4236/jpee.2015.39002

Dr. Nkoi is a member of the following professional societies: Nigerian Society of Engineers (MNSE); American Society of Mechanical Engineers (ASME); Institution of Engineering and Technology (MIET), UK; Institution of Diesel and Gas Turbine Engineers (MIDGTE), UK; Registered/certified Mechanical Engineer of the Council for the Regulation of Engineering in Nigeria (COREN): Reg. No: 22421; CEng equivalent. 